AperTO - Archivio Istituzionale Open Access dell'Università di Torino

\title{
Religion in Public Spaces: A European Perspective
}

\section{This is the author's manuscript}

Original Citation:

Availability:

This version is available http://hdl.handle.net/2318/152252

since 2016-06-27T13:46:09Z

Published version:

DOI:10.1080/21567689.2014.959706

Terms of use:

Open Access

Anyone can freely access the full text of works made available as "Open Access". Works made available under a Creative Commons license can be used according to the terms and conditions of said license. Use of all other works requires consent of the right holder (author or publisher) if not exempted from copyright protection by the applicable law. 


\section{(3) \\ UNIVERSITÀ DEGLI STUDI DI TORINO}

This is an author version of the contribution published on:

Ozzano L.

Religion in Public Spaces: A European Perspective

Politics, Religion and Ideology (2014) 15 (4)

DOI: $\underline{10.1080 / 21567689.2014 .959706}$ 
The demographic and cultural profile of Europe is becoming increasingly complex as a consequence of both processes of secularization and migration, which make European society more pluralistic and create new challenges for decision-makers. As a consequence of such dynamics, religious matters are more and more relevant in the domestic debates of several European countries, as well as in the larger debate about the cultural roots of the European Union (EU) itself. Among the major conflicts revolving around the role of religion in the public sphere, as well as the relations between different religious traditions, we can mention the affaire du foulard in France, the debate on the recognition of same-sex marriage in several European countries, the debate over the legalization of euthanasia in Belgium and the Netherlands, the controversies sparked by the Danish 'Muhammad cartoons', and the recent debate about abortion in Spain, only to mention some of the best known cases.

This edited book aims at understanding such phenomena, and includes the proceedings of a colloquium held in 2010 under the aegis of the RELIGARE (Religious Diversity and Secular Models in Europe. Innovative Approaches to Law and Policy) Project, funded by the EU under the Seventh Research Framework Programme. The book is divided into three parts. The first includes contributions looking at the public/private divide from different theoretical points of view, providing a background for the following sections. The second is entitled 'Religion and Dress Codes' and is focused on some debates revolving around religious prescriptions about clothing, mainly (but not exclusively) in relation to Islam. The third part deals instead with another hot issue related to European religious pluralism: the construction and the maintenance of places of worship. After an introduction by Marie-Claire Foblets which describes the RELIGARE Project and its aims, as well as the structure of the book, a chapter by Kjell $\AA$. Modéer sets the frame for the following contributions in historical-legal terms, by briefly summarizing the evolution of the public/private divide and the role of religion in the European public sphere from the Protestant Reformation, to Enlightenment and its consequences, to the contemporary era. The following contribution, by Adam Seligman, also considers the public/private divide in historical perspective, although under a sociological point of view, showing how the privatization of 'the realm of value' makes it more difficult to represent the collective whole. The fourth chapter presents a more elaborated contribution by Veit Bader about 'The "Public-Private" Divide on Drift', aiming both at providing some clarifications and definitions of the concepts of 'private' and 'public' and their divide, and at discussing the moral principles behind the interventions of public authorities in religious organizations. The author effectively shows that the public/private divide, as well as the status of religious organizations changes according to the different national contexts, while in many cases they are neither public nor private, but rather something 'in-between': according to his point of view, therefore, the public/private divide is not as decisive as it often looks to scholars. Bader's work is followed by another challenging contribution on the distinction between public and private, by Alessandro Ferrari, who warns about the danger of the adoption of 'double standard secularism', with a softer approach towards traditional 'secularized' religions, and a harder one toward religions such as Islam, allegedly less secularized, by driving them 'back into a hermetic public sphere' (p. 75). Jean-François Gadreault-DesBiens and Noura Karazivan also raise the question of the public/private divide, by showing the differences between common law and civil law countries, leading, according to the authors, to different attitudes and different regulations of religion; Hanne Petersen even questions the legitimacy of the concept of the public/private divide itself, as the alleged product of the influence of the worldview of monotheistic religions, perpetuating both gender and class inequalities. This section is concluded by a contribution by one of the editors, Silvio Ferrari, providing 'a legal overview' of the role of religion in public spaces in Europe. This chapter should prove particularly interesting for scholars dealing with religion in the public sphere, since Ferrari sets out three different patterns of regulation: the first, spread in several Orthodox- and Catholic-majority countries, such as Italy, 'is based on the conviction that traditional values can still play a relevant role in granting the national cohesion', and 'therefore they deserve a special position in the public sphere' (p. 140); the second, 'French', model, is instead 'based on the conviction that 
national identity and social cohesion can no longer be granted by traditional religions' (p. 141), and tries to build a common citizenship around a set of secular principles; the third, 'multicultural' pattern is instead exemplified by the United Kingdom, where the courts rather than the representative institutions play a crucial role in striking a balance between the different groups coexisting in society. The author then shows that each of the three models has its own limitations, and suggests as a solution the deconstruction of the notion of the public sphere itself, with a separation of a common, political and institutional space.

After this dense and challenging set of theoretical points of view, the following section enters more directly the specific debates, by addressing different issues related to religious prescriptions on clothing (and the desire of many believers to accommodate them in school and workplace contexts) and their regulation in different European countries. A comparative contribution on religious dress codes in workplaces in different European contexts, by Katayoun Alidadi, starts this section of the book: according to the author, the definition of 'public spaces' adopted in the different countries 'has significant consequences for legal practice, including which rules apply and what approaches are taken towards the labour market'. In relation to the headscarf issue, this is reflected in different ways in the distinction between 'front-office' and 'back-office' positions in workplaces, adopted in several contexts to deal with the issue. The following contributions address the issue through singlecase studies, starting with Turkey, dealt with by A. Emre Öktem and Mehmet C. Uzun. This work comprehensively describes the different, 'burdensomely detailed' (p. 215) regulations about the use of the veil, which are in place for both civil servants and students: according to the author, in Turkey we can find a kind of hypertrophic idea of the 'public sphere', which allows the legislator to intervene in most aspects of citizens' lives, in order to ensure the respect of Kemalist secular principles. On the other hand, in the United Kingdom case, addressed by Javier Garcia Oliva, a multiculturalist approach has allowed the accommodation of many practices, such as the Islamic headscarf, in the public sphere. According to the author, the United Kingdom case - despite some shortcomings and inconsistencies in the courts' decisions - shows that 'religious freedom must be a protective umbrella for believers, atheists and agnostics' (p. 232), setting an example for many European countries. The Italian case, addressed in the following contribution by another editor of the book, Sabrina Pastorelli, is also very peculiar, both for the presence in the country of a large Catholic majority, and for the rise, in the latest decades, of political entrepreneurs eager to exploit issues related to identity and religious values to garner more votes. The contribution deals particularly with cases related to the use of both the turban and the ritual kirpan by Sikh immigrants, and with the better-known cases related to the Muslim veil. In relation to this issue, the chapter proposes a thorough description of the different attempts to ban the burqa, both in the Italian parliament and in local administrations led by the xenophobic Lega Nord party. The contribution also highlights the different frames used by the media in covering the cases related to the two communities, with a softer attitude towards the Sikh, and a harder stance towards the Muslims, often portrayed as a threat to security. An Eastern European case, Bulgaria, is addressed by Maya Kosseva and Iva Kyurcheva in the following chapter: according to the authors, traditionally in the country 'the various religious and ethnic groups have freely demonstrated their group affiliation through their clothing' (p. 255), without inciting any serious debate. However, both changing dress codes (particularly related to the use of the veil by young students) and changing institutional attitudes have recently led to debates about the use of veils in public schools as well as in photos for personal identification documents. This section is concluded by a chapter about 'Comparing Burqa Debates in Europe', in which Sara Silvestri addresses the issue of the integral veil in comparative perspective, by analyzing both different sartorial styles and symbolic meanings and different regulations throughout the continent. According to the author, both common people and legislators often make up their minds on this issue based on misleading information related to the use of the full veil in Muslim-majority countries such as Saudi Arabia and Afghanistan, rather than in relation to the use of Islamic garments in their local context. Moreover, according to the author, the burqa is often only an excuse to exercise deeper fears related to immigrants at the economic level. 
As already mentioned, the final section of the book deals with places of worship. Although the right to have a place of worship is granted to all religious groups by several international laws and court decisions, this right is far from being granted everywhere in Europe, especially in relation to minorities. Minorities' demands to have proper places of worship have increased in recent years and have as a result led to fierce disputes in several European countries. The first contribution of this section, by Noel G. Villaroman, introduces the subject in legal terms, with a review of the different rights connected to the broader right to have a place of worship, from the right to acquire ownership of real property, to the right against discrimination. According to the author, every violation of these specific rights necessarily entails a curtailment of the freedom of religion and belief. Anne Fornerod then analyzes the French case in relation to the public/private divide. The country traditionally grants the right to worship, while, at the same time, forbidding all public funding of religion, a balance which is increasingly difficult to strike in a time of religious pluralization in which religious activities are more and more difficult to distinguish from other kinds of activities. The following contribution, by Vincenzo Pacillo, analyzes the controversial debate about the ban on minarets in Switzerland, showing that in the country (as well as in neighboring Italy) there are powerful xenophobic forces opposing the accommodation of religious practices of immigrant groups in the Swiss public sphere, which also forces the national and local governments to take a cautious approach in relation to such matters. The last chapter, by Tymen J. van der Ploeg, takes into account the issue in comparative perspective, by analyzing different aspects of worship in the Bulgarian, Italian, and Dutch cases, concluding that, at least in legal terms, there are several commonalities among them, from the private status of the places of worship, to the problems raised by more public acts such as the call to worship; but also differences, for example in terms of public funding of religion.

As a whole, this book is a very interesting and challenging work, providing perhaps the most comprehensive review of the debates related to religious minority issues in Europe, both in terms of theoretical elaboration and in terms of case studies. Although the book addresses the subject mainly from a legal perspective, the contributions included in it often provide precious insight also into other aspects related to the accommodation of religious practices in the public sphere, in sociological and political terms. Therefore, its consultation is suggested for all scholars dealing with the role of religion in the European public sphere, as well as with the new challenges created by globalization processes and migration flows in Europe. 